\title{
A Case of Active Acromegalic Woman with a Marked Increase in Serum Insulin-like Growth Factor-1 Levels after Delivery
}

\author{
YOSUKE OKADA, ISAO MORIMOTO, KUNIAKI EJIMA*, KOHJI YOSHIDA*, \\ MASAMICHI KASHIMURA*, TAKASHI FUJIHIRA, AND SUMIYA ETO \\ First Department of Internal Medicine, and *Department of Obstetrics and Gynecology, \\ University of Occupational and Environmental Health Japan, School of Medicine, Fukuoka 807, Japan
}

\begin{abstract}
Pregnancy in a woman with active acromegaly is very rare, because amenorrhea, due to hyperprolactinemia and disturbed pituitary gonadotropin secretion may cause infertility. We report a 28-year-old pregnant woman with untreated acromegaly, who was followed up from early pregnancy to delivery. Her pregnancy was uneventful, and she went into spontaneous labor at 38 weeks and delivered a normal infant. Her serum GH levels were further increased in late pregnancy, followed by decreased in postpartum periods, which may be associated with enlargement of pituitary adenoma during pregnancy. In contrast with serum $\mathrm{GH}$, her serum insulin-like growth factor-1 (IGF-1) levels were dissociated with her serum GH levels during late pregnant and postpartum period. Her serum GH and IGF-1 levels in late pregnancy were different from the levels in pregnant women with acromegaly reported previously.
\end{abstract}

Key words: Acromegaly, Pregnancy, GH, Insulin-like growth factor-1 (IGF-1)

(Endocrine Journal 44: 117-120, 1997)

ACROMEGALY rarely occurs in women of childbearing age. Moreover, fertility is low in acromegalic women because of amenorrhea, due to a decreased gonadotropin reserve caused by the tumor mass and hyperprolactinemia observed in 30 to $40 \%$ of them. For these reasons, there are not enough data to evaluate the outcome of pregnancy or a risk of pregnancy in acromegaly. In normal pregnancy insulin-like growth factor-1 (IGF-1) originating in a placental $\mathrm{GH}$ variant is increased in late pregnancy, resulting in the suppression of pituitary GH secretion, but, in previous studies of

Received: May 11, 1996

Accepted: October 16, 1996

Correspondence to: Dr. Isao MORIMOTO, First Department of Internal Medicine, University of Occupational and Environmental Health, School of Medicine, 1-1, Iseigaoka, Yahatanishi-ku, Kitakyushu-shi, Fukuoka 807, Japan pregnant women with acromegaly [1], GH secretion from adenomatous somatotrophs remained high during the third trimester of pregnancy despite a rise in serum IGF-1 derived from the placenta. Here we report a pregnant woman with untreated acromegaly who showed dissociated serum levels of GH and IGF-1 in late pregnancy.

\section{Case Report}

A 28-year-old nulliparous woman first visited the department of obstetrics because of infertility 2 months before and was referred to our clinic because of acromegalic characteristics and high blood glucose $(246 \mathrm{mg} / \mathrm{d} l)$. Her menarche was at age 13, and since then her menstrual cycles had been regular. At 20 years of age she became aware of an enlargement of her nose, lips and extremities and a widening of spaces between her teeth. She 
had been infertile for 2 years despite a regular menstrual cycle. Physical examination revealed that her height was $171 \mathrm{~cm}$ and weight was $79 \mathrm{~kg}$. She had acromegalic characteristics associated with deepening of voice, coarse skin, soft tissue hypertrophy, thickened digitus and extremities, and prognathism. No abnormal findings were observed on ophthalmologic examination including optic fundi, visual acuity and visual field. Her fasting plasma glucose was $124 \mathrm{mg} / \mathrm{d} l$. Hemoglobin $\mathrm{A}_{1 \mathrm{c}}\left(\mathrm{HbA}_{1 \mathrm{c}}\right.$ ) was $7.4 \%$ (normal: 4.06.0\%) and urinary C-peptide was $209.7 \mu \mathrm{g} /$ day (normal: 16-120 $\mu \mathrm{g} /$ day). Serum GH measured with a two-site immunoradiometric assay kit using two different monoclonal antibodies (Daiichi Radioisotope Labs., Ltd, Tokyo, Japan) was 21.9 $\mathrm{ng} / \mathrm{ml}$ (normal: $0.66-3.8 \mathrm{ng} / \mathrm{ml}$ ). The antibodies used in the kit did not crossreact with placental GH or placental lactogen. Serum IGF-1 measured with an immunoradiometric assay kit (Chiba Corning Labs., Ltd, Tokyo, Japan) after the extraction of serum by ethanol was $828 \mathrm{ng} / \mathrm{ml}$ (normal female: $121-436 \mathrm{ng} / \mathrm{ml}$ ). On the other hand, serum IGF-binding protein-3 (IGFBP-3) measured by an immunometric assay kit (Diagnostic Systems Laboratories Inc, Webster, Texas, USA) was $6.9 \mu \mathrm{g} / \mathrm{ml}$ (normal females: 3.2$4.2 \mu \mathrm{g} / \mathrm{ml}$ ). A paradoxical increase in serum GH was observed in the $75 \mathrm{~g}$ oral glucose tolerance test $(33.3$ to $52.9 \mathrm{ng} / \mathrm{ml})$. Serum $\mathrm{GH}$ levels were also increased from 22.7 to $107.1 \mathrm{ng} / \mathrm{ml}$ and from 30.5 to $48.7 \mathrm{ng} / \mathrm{ml}$ by the iv administration of LH$\mathrm{RH}(100 \mu \mathrm{g})$ and TRH (500 $\mu \mathrm{g})$, respectively. The secretion of other anterior pituitary hormones, including PRL, was normal. The administration of bromocriptine $(2.5 \mathrm{mg}$ ) suppressed her serum PRL levels, but not serum GH. A brain magnetic resonance imaging (MRI) revealed that she had a $10 \mathrm{~mm}$ pituitary adenoma and no evidence of suprasellar extension (Fig. 1A). When she was diagnosed as having acromegaly due to a pituitary $\mathrm{GH}$ secreting tumor, she was 8 weeks pregnant. As she and her husband strongly wished to have the baby, regardless of the hazards, she was followed up without any medication.

Her diabetes mellitus was controlled by a 1800 Kcal diet in the first trimester, and then followed up with $2000 \mathrm{Kcal}$ in the second trimester and 2200 Kcal in the third trimester. Her fasting blood glucose levels were $100-120 \mathrm{mg} / \mathrm{d} l$, and her $\mathrm{HbA}_{1 \mathrm{C}}$
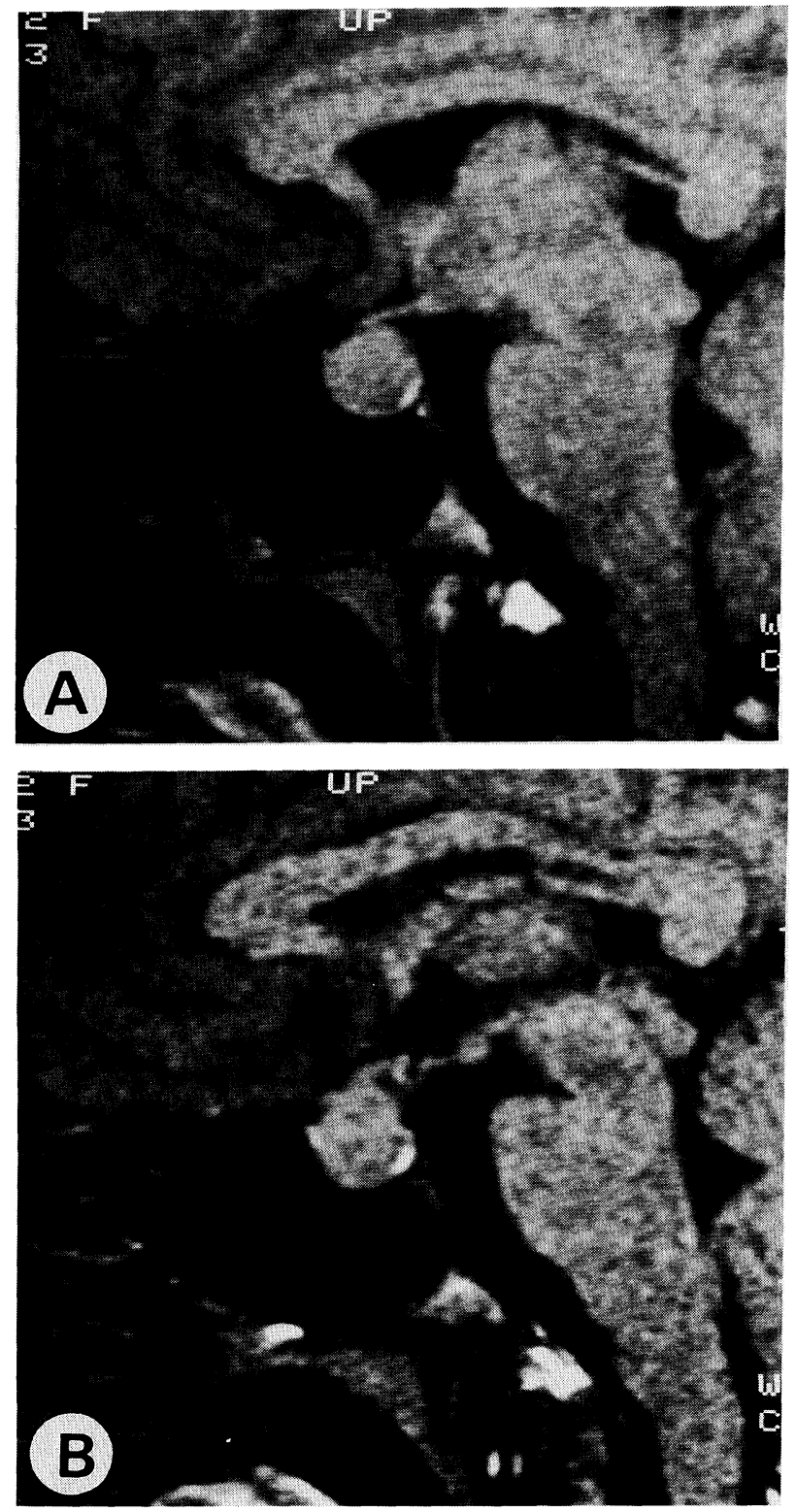

Fig. 1. A: A brain MRI revealed that she had a $10 \mathrm{~mm}$ size of pituitary microadenoma and no evidence of suprasellar extension at 8 weeks of gestation. B: A brain MRI revealed a suprasellar extention of her pituitary tumor at 34 weeks of gestation.

values were $6.0-6.4 \%$ during the gestational period. At 38 weeks she went into spontaneous labor and delivered a normal female infant (weight: $2882 \mathrm{~g}$ ) without any complications.

Her serum GH levels were maintained at 20.0 $28.8 \mathrm{ng} / \mathrm{ml}$ until 31 weeks of gestation, and were increased to $92.8 \mathrm{ng} / \mathrm{ml}$ and $74.4 \mathrm{ng} / \mathrm{ml}$ at 35 and 
Table 1. Serum GH, IGF-1, estradiol during pregnancy and postpartum in an acromegalic patient

\begin{tabular}{lccccccccc}
\hline & & \multicolumn{9}{c}{ Pregnant period (weeks) } & \multicolumn{3}{c}{ Delivery } & \multicolumn{2}{c}{ Post partum period (weeks) } \\
& & 8 & 24 & 31 & 35 & 38 & $\downarrow$ & 1 & 2 \\
\hline GH & $(\mathrm{ng} / \mathrm{ml})$ & 28.8 & 25.2 & 25.3 & 92.8 & 74.4 & & 28.2 & 26.3 \\
$\mathrm{IGF-1}$ & $(\mathrm{ng} / \mathrm{ml})$ & 828 & 855 & 655 & 817 & 553 & & 1580 & $1750<$ \\
$\mathrm{E}_{2}$ & $(\mathrm{pg} / \mathrm{ml})$ & 320 & 8300 & & & 28000 & & 130 & 64 \\
$\mathrm{IGFBP}-3(\mu \mathrm{g} / \mathrm{m} l)$ & 6.9 & 8.5 & 5.7 & 8.3 & 6.2 & & 5.4 & \\
\hline
\end{tabular}

IGF-1, insulin-like growth factor-1; E2, estradiol; IGFBP-3, IGF-binding protein-3.

38 weeks (just before delivery), respectively (Table 1). The levels decreased rapidly after delivery and were 28.2 and $26.3 \mathrm{ng} / \mathrm{ml}$ at 1 and 2 weeks postpartum, respectively. Serum IGF-1 levels were $553-855 \mathrm{ng} / \mathrm{ml}$ during the pregnancy. In contrast with the serum GH levels, the serum IGF-1 levels rose to 1530 and more than $1750 \mathrm{ng} / \mathrm{ml}$ at 1 and 2 weeks after delivery. We also carefully checked concerning about pituitary apoplexy with the tumor expansion in pregnancy. A brain MRI was carried out at 8, 20 and 34 (Fig. 1B) weeks of gestation and at 4 weeks after delivery. The MRI revealed a suprasellar extension of her pituitary tumor in the third trimester, but she did not have any abnormality of the visual field. Her pituitary tumor at 6 months after delivery was smaller than at 4 weeks after delivery. She was operated on by transsphenoidal approach 6 months after delivery, and her serum GH and IGF-1 levels were $0.1 \mathrm{ng} /$ $\mathrm{m} l$ and $80 \mathrm{ng} / \mathrm{ml}$, respectively, at 6 months in the follow-up period.

\section{Discussion}

This acromegalic woman had a 2-year history of infertility despite preserved gonadotropin secretion and normal serum PRL levels, but pregnancy was unexpected when she was diagnosed as having acromegaly in our clinic. Her pregnancy was uneventful and no complications were observed during pregnancy, despite the further enlargement of her pituitary adenoma in the third trimester. Unsolved problems are the outcome of a pregnancy and the risk of complications developing during pregnancy in acromegalic women. A mild acromegalic state does not appear to be an obstacle to a normal pregnancy [2]. This patient with a $\mathrm{GH}$ secreting adenoma did not have any complications during pregnancy despite the enlargement of her pituitary adenoma associated with an increase in serum GH levels during late gestation. Indications for surgery during pregnancy are not clear, though patients who have undergone hypophysectomy during gestation have maintained an uneventful pregnancy [3].

It is well established that during the second half of a normal pregnancy, the human placenta secretes its specific $\mathrm{GH}$ variant and IGF-1 in increasing amounts up to delivery and the serum concentration of IGF-1 rises in late pregnancy, resulting in the inhibition of normal pituitary $\mathrm{GH}$ secretion $[4,5]$. Becker $e t$ al. reported two pregnant women with acromegaly whose pituitary GH secretion remained high during the entire pregnancy, whereas serum IGF-1 levels rose in late pregnancy [1]. They hypothesized that in acromegalic women, placental GH is the main stimulator of IGF-1 secretion in late pregnancy and adenomatous somatotrophs lack an IGF-1 dependent negative regulatory mechanism. Nevertheless, it is to be noted concerning our acromegalic patient that serum IGF-1 levels fell in late pregnancy in contrast with her first trimester, and her serum GH levels rose. After delivery, serum GH levels rapidly returned to the former levels and IGF-1 levels rose noticeably. In this patient, the oversecretion of GH in late pregnancy may be associated with the enlargement of the pituitary tumor. Estrogens also exert their stimulatory effect on $\mathrm{GH}$ secretion directly on the pituitary [6, 7]. On the other hand, the administration of estrogens to acromegalic patients causes a reduction of serum IGF-1 (somatomedinC) bioactivities and serum IGF-1 concentrations without consistent changes in serum GH levels, 
which results in an improvement in the clinical status and biochemical abnormalities [8]. In this patient serum estrogen levels may associate with the oversecretion of $\mathrm{GH}$ from adenomatous somatotrophs in late pregnancy and with a marked increase in serum IGF-1 levels in postpartum period. But the oversecretion of estrogen cannot account for the reduction in serum IGF-1 levels in late pregnancy, because serum IGF-1 levels in the third trimester rise in both normal and acromegalic pregnant women [1]. We could not explain the changes in serum IGF-1 during the late pregnant and postpartum periods in this patient.

\section{Acknowledgment}

We thank Dr. Naomi Hizuka (Tokyo Women's Medical College) for measuring IGFBP-3.

\section{References}

1. Beckers A, Stevenaert A, Foidart JM, Hennen G, Frankenne F (1990) Placental and pituitary growth hormone secretion during pregnancy in acromegalic women. J Clin Endocrinol Metab 71: 725-731.

2. Cundy T, Grundy EN, Melville H, Sheldom J (1984) Bromocriptine treatment of acromegaly following spontaneous conception. Fertil Steril 42: 134-136.

3. Kupersmith MJ, Rosenberg C, Kleinberg D (1994) Visual loss in pregnant women with pituitary adenomas. Ann Intern Med 121: 473-477.

4. Wilson DM, Bennett A, Adamson GD, Nagashima RJ, Liu F, Denatale ML, Hintz RL, Rosenfeld RG (1982) Somatomedins in pregnancy; A crosssectional study of insulin-like growth factors 1 and 2 and somatomedin peptide content in normal human pregnancies. J Clin Endocrinol Metab 55: 858-861.

5. Mills NC, D’Ercole AJ, Underwood LE, Ilan J (1986)
Synthesis of somatomedin C/insulin-like growth factor 1 by human placenta. Mol Biol Rep 11: 231236.

6. Jansson JO, Eden S, Isaksson O (1985) Sexual dimorphism in the control of growth hormone secretion. Endocrine Rev 6: 129-150.

7. Ho KY, Evans WS, Blizzard RM, Veldhuis JD, Merriam GR, Samojlik E, Furlanetto R, Rogol AD, Kaiser DL, Thomer MO (1987) Effects of sex and age on the 24-hour profile of growth hormone secretion in man: Importance ofendogenous estradiol concentrations. J Clin Endocrinol Metab 64: 51-58.

8. Clemmons DR, Underwood LE, Ridgway E, Kliman B, Kjellberg RN, Wyk JJV (1980) Estradiol treatment of acromegaly; Reduction of immunoreactive somatomedin- $C$ and improvement in metabolic status. Am J Med 69: 571-575. 